\title{
Review on Contribution of GIS and RS for Soil Degradation Assessment in Ethiopia
}

\author{
Endale Bekele Jiru \\ Bonga University College of Agriculture Resource, Department of Natural Resource, Bonga Ethiopia \\ Dilla Unversity College of Agriculture Resource, Department of Natural Resource, Dilla Ethiopia
}

\begin{abstract}
GIS and RS are an advanced tools and playing a great role in natural resource management, particularly for assessing soil degradation. Soil degradation is the chronic problem in the world including Ethiopia. To review the contribution of GIS and RS, data collected from secondary data sources then discussion made based on their key findings.Accordingly, a few authors have assessed soil degradation by using GIS and RS integrated with USLE in Ethiopia. According to their findings, land degradation in the form of soil erosion is a critical issue. It is triggering by water soil erosion. Because of soil erosion, the potential capacity of the soil highly deteriorated. The amount of soil loss estimated in a different place all above the maximum (22t ha-1 year-1) soil loss tolerant considered for Ethiopia. Consequently, it threatens economic growth, environmental resource, and social assets. Moreover, its severity is uneven in all parts of the country. Even though the study conducted on soil degradation by using GIS and RS technique, its contribution is yet not pronounced to government organizations, NGOs, policymakers, and decision-makers, environmentalist and researchers in reviewed form. This will be reducing the attention that could be given to it. Therefore, to tackle this issue, this paper aimed to review the GIS and RS contribution for soil degradation assessment in Ethiopia.
\end{abstract}

Keywords: GIS, RS, Soil degradation, Soil loss, and effects

DOI: $10.7176 / \mathrm{JEES} / 9-12-01$

Publication date: December $31^{\text {st }} 2019$

\section{Introduction}

GIS and remote sensing are principal techniques in natural resources management. Today, soil degradation in the form of soil erosion is a critical issue throughout the world including Ethiopia (Mitiku et al., 2006). It is the process of worsening the quality, function, and services of the environment particularly soil resources (Rabia, 2012), which in turn, negatively affecting economic development, and farmer's livelihoods in the rural area. It is a chronic problem in Ethiopia (Berry, 2003; Nyssen et al., 2004). It is manifested itself in the forms of physical, chemical and biological deterioration (Mitiku et al., 2006; Rabia, 2012).

In Ethiopian highland, the rate of soil erosion is very severe and reached up to 300 tons per hectare annually (FAO, 1984; Tamirie, 1997). From cultivate land soil loss is ranging from 130 - $170 \mathrm{t}$ ha -1 year-1 (Hurni et al., 2010). GIS and RS can estimate the amount of soil loss integrated with USLE (Gizaw and Degifie, 2018; Tesfaye et al., Woldemariam et al., 20182018).

Ethiopia country has a total land surface area of 111.8 million hectares; from these around 60 million hectares of agricultural productive land, around 27 million hectares are significantly eroded by water erosion (sheet and rill), 14 million hectares are seriously eroded and 2 million hectares reached at irrevocable level (FAO, 1984; Fikru, 1990). Consequently, there is a significant negative impact emerged on the land itself as on-site effects and to other places as an off-site effect. Top fertile soil removed away by erosion agents like water (56\%) and wind (28\%). As a result crop yield too low (Sertsu, 2000) and the amount of yield collected per year is one to three percent while population growing by 3.3\% rate (Mitiku et al., 2006) in further food insecurity and poverty increases.

On the other side, the soil is the mainstay resource for the agricultural sector in developing countries, particularly in Ethiopia. Because around $85 \%$ of farmer's livelihood is depended on agriculture activity and relatively activity, it contributes around $45-50 \%$ GDP of the economy.

According to the sort of scholars reported that soil degradation triggered by two major causes. Anthropogenic activities took more portion than natural causes for accelerating land degradation through soil erosion (Emiru and Taye, 2012; Rabia, 2012; Tsegaye et al., 2010). People could accelerate soil erosion and land degradation around 60 to $80 \%$ (McNeill, 2000). The interaction of human beings with the environment is accounted for as the major cause of land degradation (such as inappropriately land use, overgrazing, land-use changes, deforestation, etc.) which already known as desertification (Hailu, 2017). These and other causes of soil erosion easily assessed by using GIS and RS (Bekele et al., 2018a; Gebrekidan et al., 2018; Temesgen et al., 2016).

To overcome the above-mentioned problems, the Ethiopia government incorporated with various NGOs has been developing strategic plans to halts the crisis of soil degradation particularly soil erosion since the 1970s (Mekonnen et al., 2015). However, often it has many confines, amongst them; lack of using modern technology 
tools (e.g. GIS and RS) is huge challenges. Most of the activities (both physical and biological) implemented by community-based participatory watershed management are not entirely used GIS and RS. Because the watershed attribute is several and very complex and it is problematic to understanding and delineating it with manual methods. Consequently, most implemented soil and water conservation structures are left at an infant stage or unsuccessful.

However, from the researcher's point of view, a few scholars have conducted assessments on soil degradation and predicting its status by using GIS and RS tools through integrating with the USLE or RUSLE erosion model in different parts of the country.

GIS and RS are technical tools, which is playing a great role for assessing, analyzing and screening a direction for how the above-mentioned problems solved. GIS and RS integrated with USLE or RUSLE contribute incredible benefits. For example, it used to examine watershed characteristics and delineate (Gebre et al., 2015; Chernet, 2018), identify eroded area, estimate amount of soil loss and prioritize soil severity area (Lencha and Moges, 2015; Demeke and Andualem, 2018; Gizaw and Degefie, 2018). Also, it helps for assessing land use land cover change (LULCC) and its impacts (Worku et al., 2014; Bekele et al., 2018a; Bekele et al.,2018b; Gashaw et al.; 2014). Besides, it helps to develop a strategic plan and recommending the appropriate mitigation measure (e.g. soil and water conservation) (Temesgen et al., 2017; Woldemariam et al., 2018; Tesfaye et al., 2018; Fenta, et al., 2017).

Even though, the importance of GIS and RS incredible in natural resource management particularly in soil degradation assessment, yet there is not collected document surrendered from already researched to a policymaker, decision-maker, and expert for those who have a skill of GIS and RS and require using it, for governmental organizations and NGOs. Generally, there is a problem in promoting the contribution of GIS and RS in sustainable natural resource management in Ethiopia.

Therefore, to limit the aforementioned problems, this paper is aimed to review the contribution of GIS and RS for assessing soil degradation.

\subsection{Objective}

\subsubsection{General objective}

To review the contribution of GIS and RS for soil degradation assessment in Ethiopia

\subsubsection{Specific objectives}

$\checkmark \quad$ To assess and discuss the role of GIS and RS for watershed delineation;

$\checkmark \quad$ To identify and discuss how GIS and RS can estimate the amount of soil loss couple with USLE or RUSLE;

$\checkmark$ To clarify and discuss the contributions of GIS and RS for identifying soil erosion hotspot area;

$\checkmark \quad$ To assess and discuss the contributions of GIS and RS for identifying causes of soil erosion

$\checkmark \quad$ To give awareness on how GIS and RS are playing for assessing the consequences of soil erosion.

\subsection{Significant of this review paper}

This review is superintended to give the following significances points: such as it may give awareness about the contribution of GIS and RS for watershed delineation, for predicting the amount of soil loss, for identifying soil erosion severity level, for prioritizing erosion hotspots area and submitted for preparing appropriate soil and water conservation. Besides, it distributes information to governmental organizations, NGOs, policymakers, decision-makers, and environmentalists about the benefits of GIS and RS for natural resource management. Finally, it may serve as secondary data for researchers, who interested to conduct a detailed study on the role of GIS and RS for soil degradation and other relative disciplines.

\section{Approaches Used}

To encounter the designed objectives, essential information was organized from secondary data. To obtain those data I followed the following steps; first, any article, related to a title, simply downloaded from Google scholar. Second, I read those downloaded articles then I selected through a purposive method by considering the assessment conducted by GIS and RS only about the watershed delineation, a soil loss estimation, identification and prioritization of severity area for intervention, a cause and a consequence of soil erosion. Then, the collected information from each article was combined by reviewing their key findings. As far as possible, a discussion was made on each finding. In the end, I put a discussed concept in the form of a table, a figure, and a narrative.

\section{Brief history of Geographic Information System and Remote Sensing}

GIS is computerized software that stores, retrieves, manipulates, analyzes and displays geographically referenced data sets, which can be used for different applications (Roy, 1993; Roy and Ravan, 1994; DeBy, 2001; Salem, 2003; Larson et al., 2004). It can manage two basic types of data known as geospatial data that define the location of a feature or object on the ground and attribute data that describe the characteristics of these features (Larson et al., 2004). GIS data represented and stored in the form of vector or raster. In a vector data structure, 
geospatial data represented as points, lines or polygons. For example, fire rings or campsites would be stored as points, trails or streams as lines and forests or recreation opportunity classes as polygons. In contrast, a raster data structure represents geospatial data in a regular grid of cells and the attribute applies to the entire cell. Raster data provide continuous coverage of an area. For example, the Digital Elevation Model showing slope, aspect and elevation in a grid for an area is a raster data structure. GIS, therefore, can offer the unique ability to link such spatial and attribute data and tries to manipulate and analyze relationships among them (Larson et al., 2004).

Remote sensing is the art and science of acquiring information about some property of an object, area or phenomena, which is not in physical contact with the objects or area under investigation (Janssen, 2001; Mironga, 2004; Bedru, 2006). Even if the subtle idea of remote sensing began in 1826s, for first-time remote sensing term utilized since 1960s and the first earth resource satellite (Landsat-1 launched since1972. Gradual developed and today there is much satellite. Currently, it used for multi-disciples. Among these disciples, natural resource management is one particularly for assessing soil erosion status, which triggers land degradation. Interactions of electromagnetic radiation (reflected or emitted) with the earth's surface measured by air-borne or space-borne sensors are used to collect data of interest in a given area and search data at fixed intervals to reveal the changes in the land use/land-cover patterns (Mironga, 2004, Janssen, 2001). Measurements and analyses are performed from remotely collected data, are usually stored as image data in the form of aerial photographs or satellite images that can be combined and examined by using GIS to represent the real-world features. Even if, remote sensing data can be processed and interpreted without other information, the best result could be obtained by linking measurements of remote sensing to ground or surface measurements and observations (Janssen, 2001).

Spatial data, which highly used in erosion mapping, mapping method validation, qualitative and quantitative erosion valuation obtained from RS. Because remotely sensed data, particularly, satellite imagery, offers repeatable measurements from huge areas with necessary spatial and temporal resolution. Further, those variables can be used to extract new or more accurate information (Lubczynski, Gurwin, 2005). Therefore, from satellite imagery, it is possible to detect eroded areas and determine their spatial range, as well as assess erosion factors like vegetation cover, slope, or soil type. Therefore, these parameters are used as input factors in USLE soil model. Often optical satellite systems commonly applied in erosion research (Vrieling, 2005). Because, it is sensors operate in the visible, near-infrared, shortwave infrared and thermal infrared parts of the electromagnetic spectrum.

Therefore, the relationship between GIS and RS is very high, because GIS use RS data for analyzing and reporting information particularly for assessing soil degradation.

\section{Contribution of GIS and RS for soil degradation assessment}

GIS and RS have an incomparable contribution for a natural resource management, particularly for soil and water conservation practice (Mekuriaw et al., 2017) and assess soil erosion rate in Ethiopia (Woldemariam et al., 2018; Tesfaye et al, .2018).

All necessary spatial data which supporting for assessing soil degradation, erosion mapping, qualitative and quantitative erosion assessment can be collected from various sources like present top sheet, soil type, types of land use map, field survey, climate condition (weather) report, earthly and airborne laser scanning, aerial photographs and satellite imagery. Among these, remotely sensed data, fundamentally satellite imagery, delivers repeatable measurements over large areas with desirable spatial and temporal resolution. A few researchers have used various types of Landsat imagery satellites to assess soil degradation.

Therefore, it is possible to extract watershed, detect degraded areas and examines soil erosion factors (e.g. vegetation cover, topography and soil type) from satellite imagery. Even though a few watershed delineations were delineated by using GIS and RS techniques, there are great problems in documenting it in Ethiopia. Inversely, there are various assessments available regarding soil loss estimation, identified erosion hotspot area and it causes. A detail discussion of these issues and others are explained as follows.

\subsection{Contribution of GIS and RS in Watershed delineation}

A watershed is defined as any surface area from which runoff resulting from rainfall is collected and drained through a common confluence point. It encompassed both environmental resources (like land, water, soil, wild animals, and vegetative) and socio-economic (people, their farming system, economic level) and interactions with land resources, coping strategies, social and economic activities, and cultural aspects. From a hydrological point of view, its definition is directly connected with runoff and drainage systems (Lakew et al., 2005). Watershed management is the old age practice (dating back to 5000 years) since agriculture began.

Watershed delineation through GIS and RS is the keystone for sustaining natural resource management (e.g. reducing soil erosion). Because it helps to identify soil erosion-prone areas based on the estimated soil loss, and designing appropriate soil and water conservation structures by considering their cost efficiency (Chernet, 2018; Kaltenrieder, 2007; Bewket and Teferi, 2009). It is possible to apply any mitigation measures against soil erosion 
without watershed delineation but it does not bring a remarkable return. Ethiopia government being comprised of watershed delineation in community-based participatory watershed management planning at the first step to reduce soil erosion through soil and water conservation measures (Lakew et al., 2005).

Therefore, a watershed can be delineated both by manuals (From top graphic map or top sheet through hand digitizing) and automatically (from Digital Elevation Model (DEM) through electronic) methods. Even though it is consuming time, less accuracy and uninteresting, most experts are still using manual methods than DEM. This may due to a lack of knowledge for how to use the GIS and RS, and inaccessibility of GIS components (e.g. hardware and software, data and skilled man) and financial limitation. The spatial distribution of the hydrophysical parameter is the source of evidence about soil erosion procedure and designing appropriate soil and water conservation, it can be emerged by GIS (Tesfahunegn et al., 2014).

Watershed delineation via DEM has procedures started from satellite image downloading up to completely delineation and suggesting appropriate mitigation measures (Figure 1). So that delineating watershed by using GIS and RS is too small in Ethiopia context. In the nearest past years, a few researchers have delineated and analysis characteristics of the watershed by using GIS and remote sensing techniques. For instance, see below Figure 2. This system is more advanced and vital in the large-scale watershed because it efficiently and accurately identifies the basic watershed attributes including drainage pattern, topographic, land use types, soil types, degraded land, and soil erosion (Gebre et al., 2015; Chernet, 2018). Both quantitative and quantitative data are very crucial for watershed delineation (Gebre et al., 2015). Chernet (2018) delineated, Ocholo (Figure 2a) and Chille (Figure 2b) micro watersheds by using GIS and Remote Sensing tools through collecting data from zonal region (shapefile (Topo sheet maps), handled GPS survey, and physical observation) and from Google earth image (SRTM-DEM and Landsat ETM+5 with $30 \mathrm{~m}$ spatial resolution). Accordingly, he had identified five land use types (e.g. degraded land, farmland, grassland, brush land, settlement, and forestland) for each watershed and determined the degraded land of 129.3 ha $(27.7 \%)$ from 468.8 ha in Chille and 94.2 ha $(30.5 \%)$ from 309.3 ha in Ocholo. As they described on base- map most areas of each watershed falls under degradation (Figure $2 \mathrm{c}$ and $\mathrm{d}$ ). Then as result, he created "developed map for Ocholo micro watershed (figure 2e ) with appropriate mitigation measures such as for degraded land; bench terrace, deep trench, stone bund and hillside terrace; for arable land: Fanya-juu, soil bund, trench, bench terrace, and cut off the drains. Moreover, for grazing land: cut and carry system, cut off drain, deep trench and area closure and for bushes land plantations of trees, and trench.

Besides, Fenta et al (2017) analyzed Agula watershed and its sub-watershed by using RS and GIS in the Eastern Tigray region, northern Ethiopia. Accordingly, they examined morphometric parameters, geometry, drainage texture and relief characteristics of the watershed and under morphometric parameters, they revealed sixth stream order, dendritic types of a drainage system, 4.46 of mean bifurcation, flow length of $48.5 \mathrm{~km}$ and shape of watershed elongated, which has low peak runoff and certainly for controlling flood. Finally, they added that understanding characteristics of the watershed is the pre-key points for planning, for managing, and for decision making about how to ensure the unsustainability of soil erosion. For further detail information, see the following table (Table 1). Coincides with this finding, Gebre et al (2015) also conducted an assessment in Chelekot micro-watershed attribute within the same region. Consequently, they explained watershed attributes; it has moderate relief and less elongated shape, drainage network is a dendritic type with stream orders ranging from first to sixth-order which is similar to Agula watershed, mean bifurcation ratio 3.3, which shows that there is drainage pattern too resistance to geological structures. They also added that GIS and RS helping for understanding the terrain parameters such as the nature of bedrock, infiltration capacity, and surface runoff of watershed. As a result, it assists as input for decision maker and designer to appropriately design and select a suitable place of soil and water conservation structure, especial for improving groundwater recharge. Not only delineating and designing but also it is used for identifying, mapping, evaluating the implemented soil and water conservation structures, which is the best method of distinguishing the place where land covered by conservation structure or not, especially from cultivate land use (Mekuriaw et al., 2017). Indirectly it is the procedure of arranging the degraded land for the next conservation. Unfortunately, this trend too rare and already fail in documentation in Ethiopia. Particularly, during mass mobilization, most implemented activities were unsupported by GIS and RS techniques. However, identifying, recording and mapping of areas where already conserved by soil and water conservation was being started by World Overview of Conservation Approaches and Technologies (WOCAT) as by (Mekuriaw et al., 2017). Therefore, to overcome the soil erosion problem through delineating watershed by using GIS and RS than the manual method is more benefit able because it is more efficient, reliable, and fast and depending on the processor capacity of the computer. 
Table 1: Drainage morphometric parameters characteristic of Agula watershed in northern Ethiopia

\begin{tabular}{|c|c|c|c|c|c|c|}
\hline $\begin{array}{l}\text { Stream } \\
\text { (U) }\end{array}$ & order & $\begin{array}{l}\text { Number } \\
\text { streams }\end{array}$ & $\begin{array}{l}\text { Stream length } \\
\text { (Lu) }\end{array}$ & $\begin{array}{l}\text { Mean stream } \\
\text { length }(\mathrm{Lm})\end{array}$ & $\begin{array}{l}\text { Stream length } \\
\text { ratio }(R L))\end{array}$ & $\begin{array}{l}\text { Bifurcation } \\
\text { ratio }(\mathbf{R b})\end{array}$ \\
\hline 1 & & 1662 & 545 & 0.33 & - & 3.75 \\
\hline 2 & & 443 & 299 & 0.67 & 2.06 & 4.34 \\
\hline 3 & & 102 & 155 & 1.52 & 2.25 & 4.43 \\
\hline 4 & & 23 & 78 & 3.39 & 2.23 & 5.75 \\
\hline 5 & & 4 & 53 & 13.25 & 3.91 & 4.00 \\
\hline 6 & & 1 & 20 & 20.00 & 1.51 & - \\
\hline
\end{tabular}

Source: adapted from Fenta et al (2017)

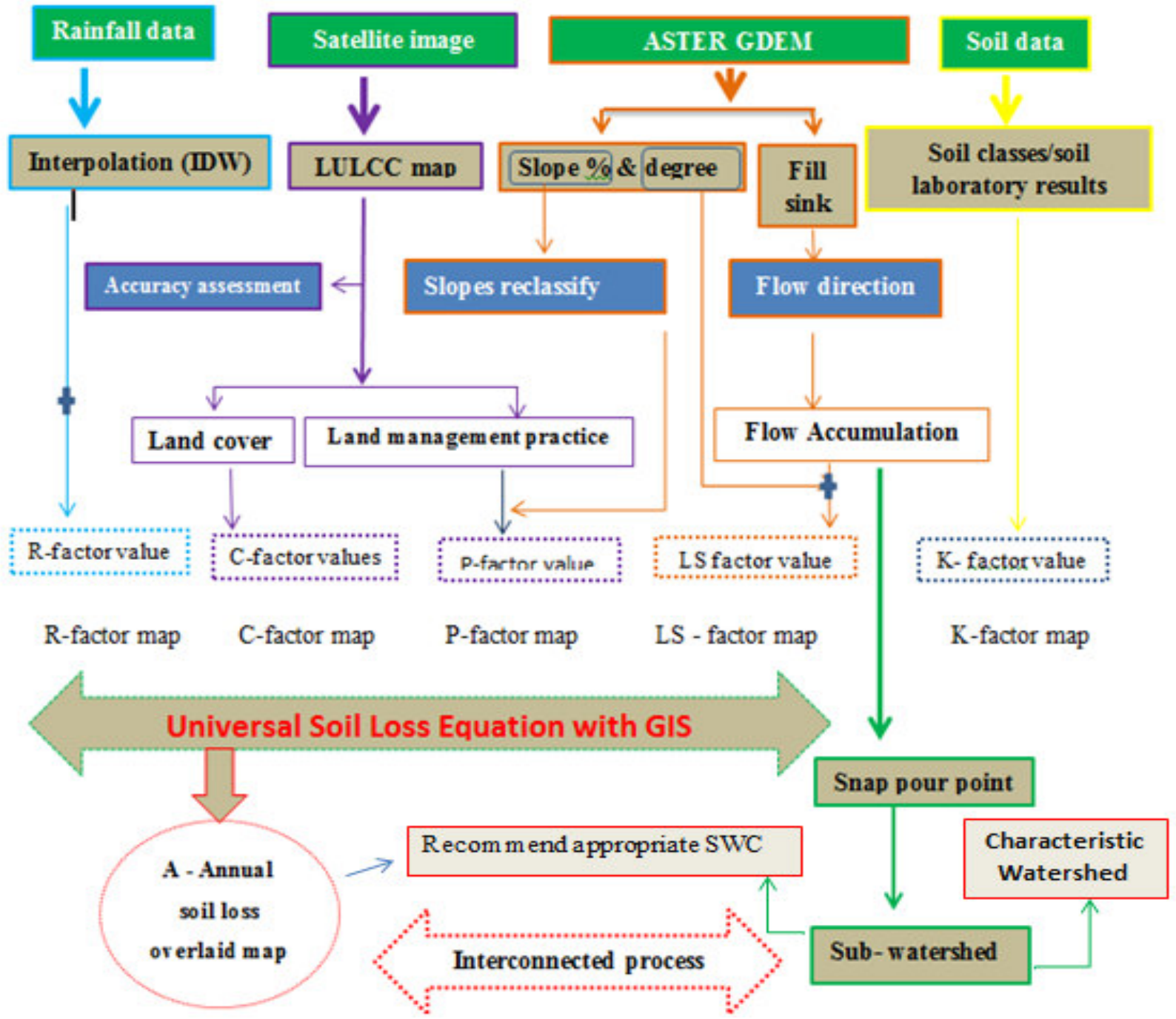

Figure 1: Flow chart prepared for GIS and RS in watershed delineation, soil loss estimation integrate with USLE Source: - Analyzed and adapted from previous finding (Gelagay and Minale, 2016; Chernet, 2018; Temesgen et al., 2017; Gizaw and Degifie, 2018; Mengie et al., 2019)

* STER= Advanced Spaceborne Thermal Emission and Reflection Radiometer, GDEM= Global Digital Elevation Model 


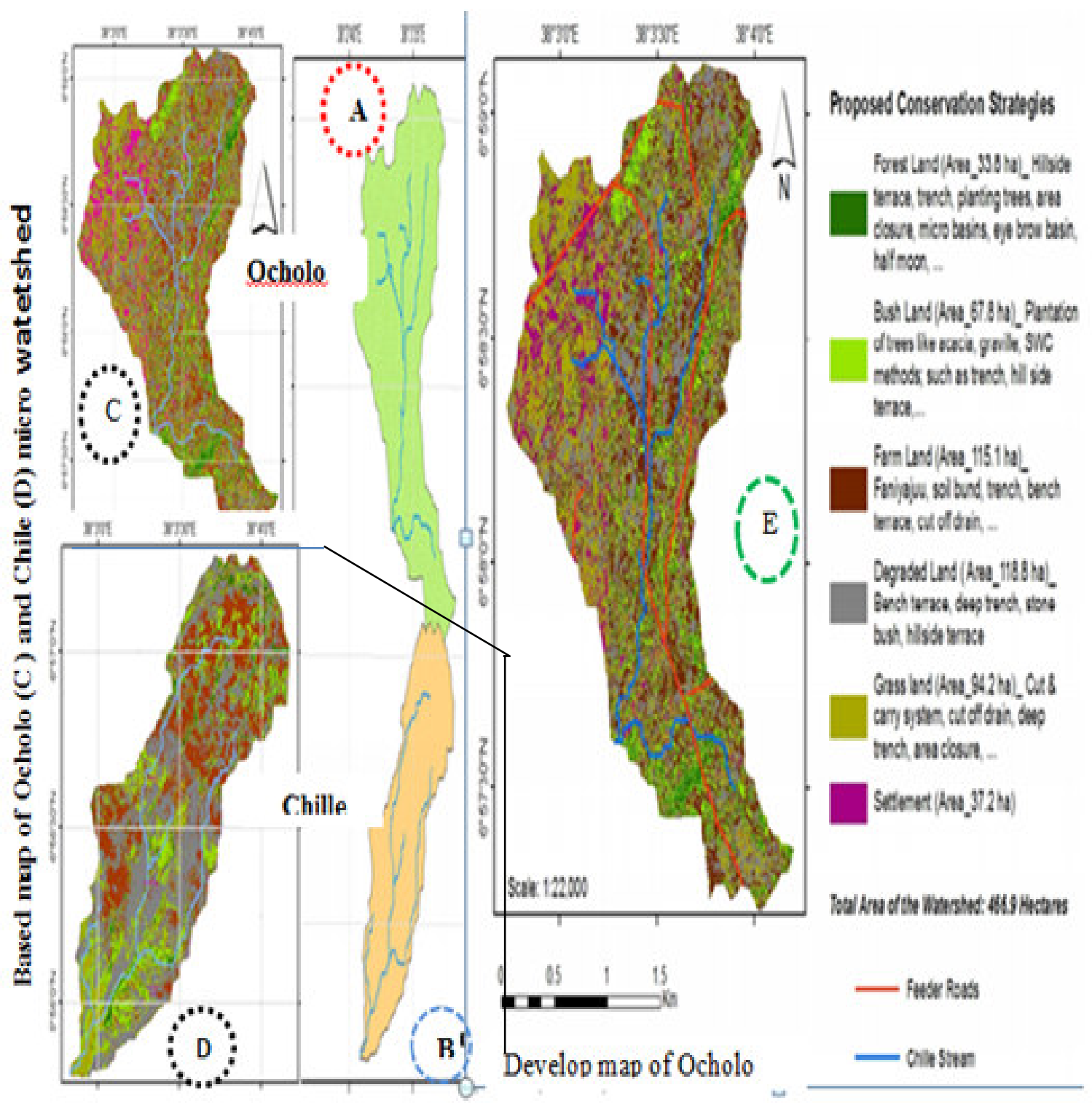

Land use land cover classes
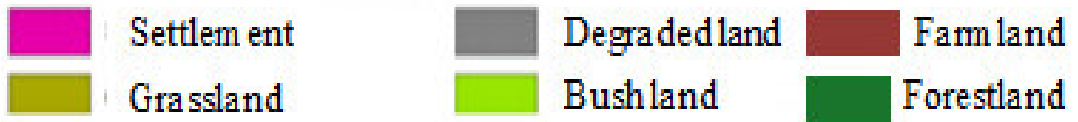

Figure 2:Watershed delineated of Ocholo (A) and Chille (B), based map of Ocholo (C) and Chille (D) and the developed map of Ocholo micro watershed (E)

Source: - Updated from Chernet (2018)

\subsection{Contribution of GIS and RS for Predicting Soil Loss}

In addition to watershed delineation, GIS and RS tools are also used for measuring potential soil loss associated with USLE or RUSLE soil erosion model (Lencha and Moges, 2015; Tiruneh and Ayalew, 2015; Gelagay and Minale, 2016; Gizaw and Degifie, 2018; Megersa et al., 2019).

The severity of soil degradation is not dreaming things rather erupted from evidence-based, in which potential soil loss computed by using GIS and RS integrated with USLE or RUSLE factors in Ethiopia. A few researchers had used GIS and RS for assessing both qualitatively and quantitatively of soil erosion, which generated by water erosion (e.g. sheet and rill) at different parts of the country.

Accordingly, Tesfaye et al (2018) conducted a study on soil erosion risk by using GIS and RS connected with the USLE model in Somodo watershed, Southwestern Ethiopia, estimated mean annual soil loss of $18.69 \mathrm{t}$ ha -1 year -1 , which is ranging from 0 to $131.2 \mathrm{t}$ ha -1 year -1 from nine sub-watershed. They added that around 
more than $20 \mathrm{t}$ ha -1 year-1 of soil loss created from more than $75 \%$ of total watershed and less than $10 \mathrm{t}$ ha -1 year-1 from $25 \%$ of total watershed (Table 3 ).

In addition, Lencha and Moges (2015) examined soil erosion spatial pattern by using GIS couple with USLE in Jimma zone, Western Ethiopia, through overlaying the USLE factors via raster calculator function by using ArcGIS tool. They have estimated total soil loss of $90.2 \times 10^{6}$ and $115.9 \times 10^{6}$ metric tons in 2001 and 2013 from total land use of $1,824,878$ ha respectively. They marked the amount of soil loss located within an interval of zero to over $50 \mathrm{t}$ ha -1 year-1. Moreover, they finally confirmed the increment of soil loss by $25.7 \times 10^{6}$ within 10 years (2001-2013) specifically around the hydropower reservoir's area (Figure 3). All most from nine districts the amount of soil loss above the maximum allowable soil loss (22 $t$ ha-1 year-1) in Ethiopia. Perhaps, before this study, there are a few soils and water conservation practices taken place or damaged by different cause, and they urgently recommended SWC intervention. Because Gilgel Gibe I hydroelectric power is located in this zone, particularly around where soil erosion severity is registered (Sekoru, Omo nada, Tiro afeta, Limu seka) (Table 4) (Figure 4). This finding contrast with Woldemariam et al (2018) finding, in which the mean annual soil loss reduced rather increasing as year increases. However, the study conducted by Gizaw and Degifie (2018) confirmed the increments of soil loss in Jimma zone, particularly in Gilgel Gibe I catchment. They estimated a mean annual soil loss of $63 \mathrm{tha}-1$ yea-1 with a range of 0 to $983.14 \mathrm{t}$ ha-1 year-1 and higher than the finding reported by others (Woldemariam et al., 2018; Tesfaye et al., 2018; Lencha and Moges, 2015).

Furthermore, Woldemariam et al (2018) also assessed spatial changes of soil erosion between the years 2000 and 2016. They have estimated a total soil loss of 1.39 million tons in 2000 and 1.02 million tons in 2016 with a mean erosion rate of $51.04 \mathrm{tha}-1$ year-1 and $34.26 \mathrm{t}$ ha-1 year-1, respectively in Gobele watershed, East Hararghe Zone, Ethiopia. Less soil loss recorded in 2016 than in 2000. This shows that there is an implemented SWC structure to ameliorate soil erosion in the watershed by local people. As results within 16 years (2000 to 2016) around $16.78 \mathrm{tha}-1$ year-1 mean of soils were protected from loss, this will highly encourage the farmers to treat their land continuously.

\section{1 由 2013}

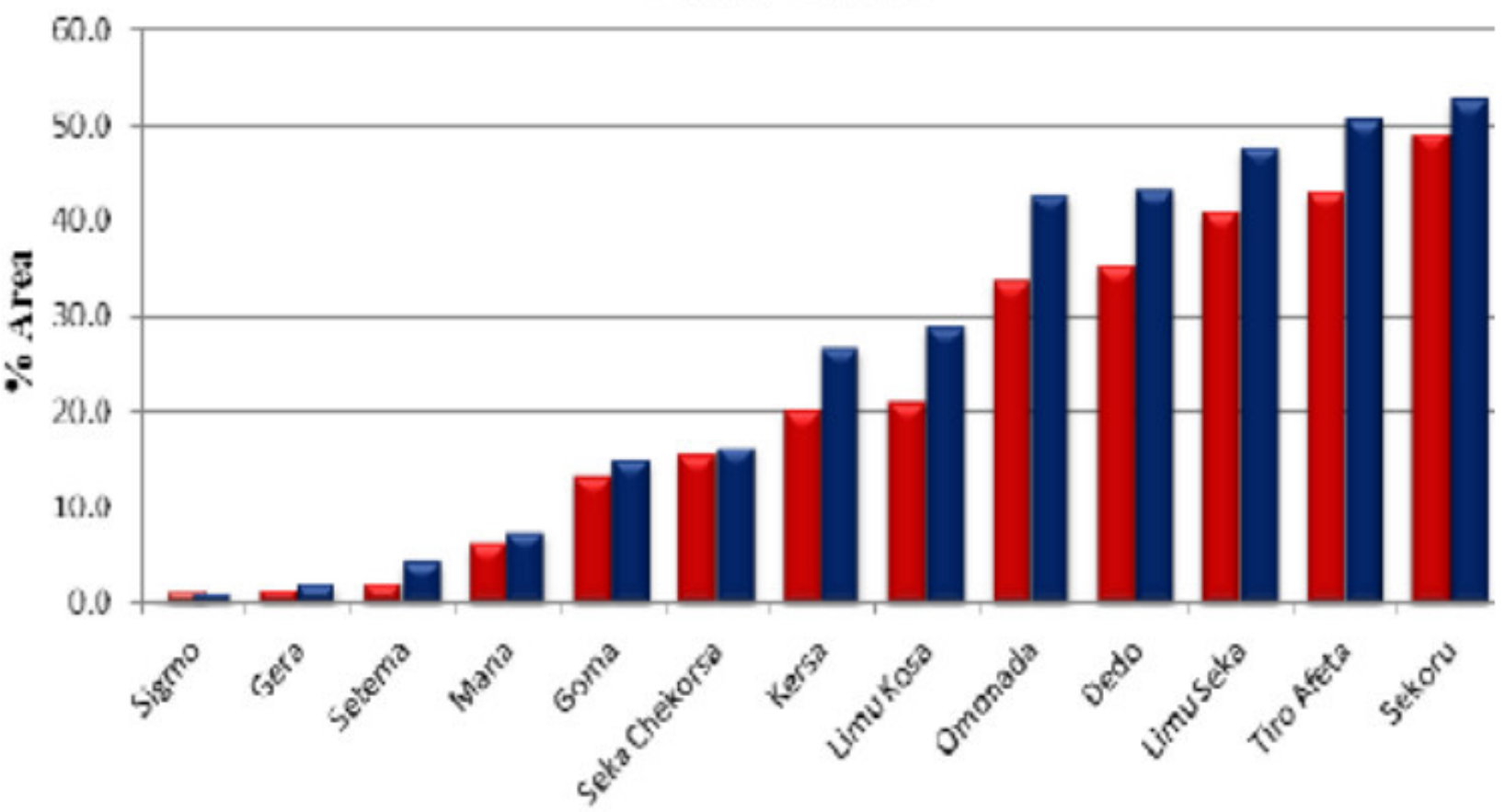

Figure 3: Areas with erosion over the allowable limits (Lencha and Moges, 2015)

In the Highland of Ethiopia, the estimated soil loss from cultivated land is ranging from $130-170$ t ha-1 year-1 (Hurni et al., 2010).

Tiruneh and Ayalew (2015) conducted a study in Enfranz watershed by application of GIS and RS associated with RUSLE in the highland of Ethiopia. For the prediction of soil loss, they had collected data for six main factors of USLE from various sources (e.g. Image satellite for C and P factors, DEM for LS, Rainfall for R factor, and soil map for $\mathrm{K}$ factor) (Figure 1). Then, they reported the total and an average soil loss of 30,836.41t year-1 and 4.81 tons ha-1year-1 respectively, which is too small when compared to the mean annual soil loss with Hurni et al (2010) and others, this shows that there is a variation in landscape and intervention of SWC.

Besides, Veeranarayana et al (2019) conducted an assessment in Megech river catchment, which located in 
the catchment of Lake Tana sub-basin, Northwestern Ethiopia, predicted total annual soil loss of 8.43 million tons with an average soil loss of 41.54 tons ha-1yr-1. They also added that soil erosion severity is unevenly distributed within catchment, this is because around $3.1 \%, 20.5 \%$ and $50.5 \%$ of the total catchment of area degraded by soil erosion extremely (50 tons ha-1yr-), moderately (greater than 10 tons ha-1 yr-1) and very low (less than 1 ton ha-1yr-1.) respectively. Estifanos (2014) also estimated 39.8 tons ha-1 yr-1 mean annual of soil loss in Ribb watershed, which located within similar catchment but adjacent to the Megech river.

Additionally, Gelagay and Minale (2016) estimated total annual soil loss of 255,283 tones, in which ranged from zero (at lowland level) to 265 metric t ha-1 year-1 (at upper land level) with a mean annual soil loss of 47.4 metric t ha-1 year-1 in Koga watershed, Northwestern Ethiopia. More than half $(75.8 \%)$ of the total area of land is located at downstream with low slope, because of this approximately $3.5 \mathrm{t}$ ha-1 year-1 of soil loss with annual total soil of $73,482.5$ tones whereas $1.35 \%$ of total land loss $162.5 \mathrm{t}$ ha-1 year-1 mean of soil (Table 2 ). Its river is flowing to Gilgel Abay River the headwater of the Blue Nile catchment. Furthermore, within the same basin but dissimilar in the watershed, Temesgen et al (2017) also estimated total annual soil loss of 157,022 with mean annual soil loss of $23.7 \mathrm{t}$ ha-1 year-, which ranged from 0 in plain areas to $237 \mathrm{t}$ ha-1 year-1 in the steepest slope areas in Geleda watershed. Even if this mean annual soil loss is less when compare with Gelagay and Minale (2016) finding, the severity level is higher at soil risk class.

Ayalew and Selassie (2015) carried out a study on soil loss by using GIS and RS couple with USLE in Guang Watershed, Blue Nile, acknowledged annual mean and total soil loss of 24.95 tons ha- 1 year-1 and $8,732.5$ t ha-1 year-1, respectively.

A mean annual soil loss estimated from above micro watershed within sub-basin of Tana catchment all are relatively less than 50 ton ha year and greater than 20 ton ha year except in Chemoga watershed. In the case of Chemoga, there is nothing intervention taken place by anybody but in others, there are a few soil and water conservation practices even if it does not reduce soil erosion as anticipated. Remembering that the rates of soil losses are unevenly distributed and severity status varied as well. Unfortunately, in Tana Lake sub-basin the rate of soil erosion is increasing. This will reduce the crop yield because almost the estimated soil loss is above the proposed soil loss tolerance unless immediate mitigation measures must be taken. Finally, Amsalu and Mengaw (2014) estimate total soil loss of 3,580,528 tons per year from a total of 116983.5 ha of land with mean annual soil loss of 30.4 tha-1 year-1 in Jabi Tehinan watershed in the northwestern highlands.

Finally, Bewket and Teferi (2009) conducted assessment in Chemoga watershed, Blue Nile basin, Ethiopia, by using satellite remote sensing and geographical information systems cohesive with USLE, computed an average annual soil loss of $93 \mathrm{t}$ ha-1 year-1, which extending from zero to $7.243 \mathrm{tha}-1$ year-1 due to rill and inter-rill erosion. This finding is higher than that of (Veeranarayana et al., 2019; Tiruneh and Ayalew, 2015; Estifanos, 2014). This may happened due to the variation of USLE factors.

Therefore, there is a procedure for predicting potential soil loss by using GIS and RS to associate with USLE or RUSLE factors. All necessary data are collected from various sources (e.g. Landsat image satellite, DEM, GPS) according to the specific objectives and the collected data analyzed with selected software (e.g. ERDAS IMAGINE for land use classification, NDVI, ArcGIS), then next the value of each USLE parameter estimated at a grid level with determined resolution size. Lastly overlaid is implemented to generate mean annual soil loss (A) by the help of a raster calculator in the ArcGIS tool see flow chart (Figure 1).

Depending on the calculated results of each USLE parameter, mean annual soil loss estimated then it interpolated with ArcGIS raster calculator and carefully mapped by using ArcGIS. Additional, after annual soil loss is estimated for each land use, watershed or land use ordered and identify soil erosion risk area then at end severity soil erosion are mapped for purpose of developing and implementing the appropriate management measure (Gelagay and Minale, 2016, Woldemariam et al., 2018; Chernet, 2018). See Ocholo micro watershed Figure 2E (Chernet, 2018).

Therefore, from soil erosion assessment conducted by GIS and RS integrated with USEL or RUSLE, the severity of soil erosion higher in the Highland parts of the country. Consequently, soil loss estimated value is situated between moderate to very severe (Estifanos, 2014; Ayalew and Selassie, 2015; Temesgen et al., 2017; Amsalu and Mengaw, 2014). Further, very few also classified under sever level (Gelagay and Minale, 2016; Veeranarayana et al., 2019). 
Table 2: Amount of soil loss range, area coverage, and severity class in Koga watershed

\begin{tabular}{lllll}
\hline $\begin{array}{l}\text { Numeric range of soil loss }(\mathrm{t} \text { ha } \\
\text { year) }\end{array}$ & Soil loss risk class & Area (ha) & $\begin{array}{l}\text { Annual soil loss } \\
\text { (tone) }\end{array}$ & $\begin{array}{l}\text { Percent } \\
\text { total area }\end{array}$ \\
\hline $0-7$ & low & 20,995 & $73,482.5$ & 75.8 \\
$7-15$ & Moderate & 3046 & 33,506 & 11 \\
$15-25$ & High & 1991 & 39,820 & 7 \\
$25-45$ & very high & 1108 & 38,780 & 4 \\
$45-60$ & sever & 173 & $9,082.5$ & 0.6 \\
$>60$ & very sever & 373 & $60,612.5$ & 1.35 \\
Total & & $\mathbf{2 7 , 6 8 6}$ & $\mathbf{2 5 5 , 2 8 3}$ & $\mathbf{1 0 0}$ \\
\hline
\end{tabular}

Source: Gelagay and Minale (2016)

\subsection{Contribution of GIS and RS in identifying soil erosion hotspot areas}

As discussed above, in the past four decades (the 1970s), the government of Ethiopia has been implemented different soil and water conservation almost in all parts of the country to restore and rehabilitate the degraded land. However, the intervened measure does not bring an anticipated result (Tesfaye et al., 2018) and soil degradation has continued in diminishing agricultural production, reducing productivity potential of land, reducing crop yield, endangers people's livelihood and pull-down economy growth (Lulseged and Vlek, 2005; Tamene and Vlek, 2005; Ayalew, 2015). This is due to the main fact reason of lack of disintegration of physical structure with biological measures, physical conservation structure required budget for construction, unwillingness of farmer to adopt labor-intensive structures, eliminate local knowledge (e.g. agroforestry practice), lack of including highly degraded farm in conservation and lack of properly managing implemented structures (e.g. private, common-pool and state farm). Besides, lack of using GIS and RS techniques, lack of precisely understanding watershed characteristics and lack of converting the documented policy into implementation in natural resource management. Among these, lack of precisely understanding watershed characteristics (both biophysical and socioeconomic) and exactly differentiating highly degraded area and ordering for intervention based on the severity and soil erosion risks and miss of utilizing GIS and RS are accounted as primary pillar of problems (Gelagay and Minale,2016; Woldemariam et al., 2018, Gebre et al, 2015; Chernet, 2018). In the above reviews, soil erosion is natural phenomena and improved by the biophysical environment such as soil, climate (rainfall and temperature), topography, management practice and their interconnections (Tesfaye et al, 2018).

Recently, distinguishing more degraded land, prioritizing for intervention, and designing appropriate soil and water conservation structure to reduce soil erosion accomplished by using GIS and RS integrate with USLE/RUSLE (Lencha and Moges, 2015; Temesgen et al., 2017; Tesfaye et al., 2018).

A few scholars conducted a study on classification and prioritizing different land use from different subwatershed and basin/catchment based on mean annual soil loss. For example, Tesfaye et al (2018) prioritized sub-watershed from the upper part of the Blue Nile river basin at Somodo watershed, Oromia regional state in the Southwestern part of Ethiopia (Table 3). From this table, SW-1 (20-30 t ha-1 year-1) and SW-5 and SW-9 (>30 tha-1 year-1) considered as high and very high soil severity areas respectively. This shows that erosion hotspot areas which need immediate intervention to ameliorate the on-site and off-site effects. Similarly, from the same basin, Temesgen et al (2017) also identified and prioritized soil severity and soil hotspots area from low to sever in Geleda watershed. Severity classes reflect the weight of soil loss per hectare hence 30-50 tha- 1 year1 and 50-237 t ha-1 year-1categorized under very high and sever classes with second and first rank category, which require instant soil and water conservation respectively.

Besides, Lencha and Moges (2015) conducted study on estimation of soil erosion in Jimma Zone. They divided soil erosion condition of all Jimma zone districts into four soil susceptibility classes in which ranged from low (0-10 t ha-1 year-1), moderate (10-25 tha-1 year-1), high (25-50 t ha-1 year-1) and very high $(>50 \mathrm{t}$ ha-1 year-1). After many analyses with USLE factors, they recognized that four districts (like Dedo, Omo Nada, Sokoru and Tiro Afeta) are considered under severely affected by soil erosion and they need the immediate intervention of soil and water conservation (Table 4).

According to Tiruneh and Ayalew (2015), soil degradation distinguished depends on the mean annual soil loss. Then, soil erosion severity classified, prioritized and submitted as hotspots area. Soil loss (high soil loss) and soil erosion risk classes (none to slight and moderate to high), which support conservationists and farmers as input for designing and implementing suitable soil and water conservation structure in Enfraz watershed, Amhara Regional State Ethiopia. Similarly, Woldemariam et al., (2018) found that the geospatial variation of soil erosion risks in different watershed and prioritized the area of land-based on amount of soil loss, which need urgent intervention $\left(1^{\text {st }}\right.$ priority to $3^{\text {rd }}$ prioritized), medium intervention ( $4^{\text {th }}$ priority to 6 th prioritized) and not currently need intervention ( 7 th prioritized to 8 final) in Gobele watershed. From the total area of the watershed, 
a relatively small area $(1.36 \%)$ of land falls under critical soil erosion risk. This clue concept is also reported by others scholars from different parts of the country (Lencha and Moges, 2015; Ayalew and Selassie, 2015; Temesgen et al., 2017; Woldemariam et al., 2018, Tesfaye et al., 2018; Gizaw and Degifie, 2018). This idea is the key point for the designer of the SWC structure and financial sponsor organization.

Additionally, Rabia (2012) conducted a study on quantify land (chemical and physical) degradation by using GIS spatial model fitting together with remote sensing in Kilte Awulaelo District of Tigray, Ethiopia, categorized soil erosion severity level into very low, low, high, moderate classes, based on the soil loss rate (e.g. when high degradation there is high soil loss). Besides, Ayalew and Selassie (2015) reported that the total watershed area around 64\% (147.9 ha) and $36 \%$ ( $202.1 \mathrm{ha}$ ) categorized under none to slight and moderate to high level of soil loss portion respectively and prioritized for mitigation measure area classified under high to very high soil loss in Gauga watershed.

In Koga watershed, which is located in the Northwestern of Ethiopia, upper catchment part of the watershed is highly affected by soil erosion than down catchment, this due to slope steepness, soil erodibility condition (e.g. Nitosols and Alisols easily exposed to erosion) and rainfall variation, lack of conservation practice (Gelagay and Minale, 2016). They also classified soil risk classes into very high (25-45 t ha-1 year-1), severe (45-60 t ha-1 year-1), very severe (greater $60 \mathrm{t}$ ha-1 year-1) from where high amount soil loss is recorded and called as hotspot area, which needs immediate intervention. Whereas, soil risk classes of moderate (7-15 tha-1 year-1) and high (15-25 tha-1 year-1) from where medium amount of soil loss and require intervention next to the first whereas low soil risk area (0-7t ha-1 year-1) (Table 2). As a result, severe soil loss happened at the upper catchment, at the upper landscape there is a reduction of soil nutrient consequence irrigable land and reservoirs destroyed at lower catchments.

Therefore, GIS and RS can identify and prioritize of the soil erosion severity level, which is the main input for farmers, government, experts and for others like NGOs, because it helps them to develop the appropriate SWC structures with appropriate place and resource needed (hand tools, budget, etc.).

Table 3: Sub-watershed classified depending on Area, soil loss, level of priority and severity in Somodo watershed

\begin{tabular}{lllll}
\hline Sub-Watershed & Area (\%) & Mean Annual Soil Loss & Priority Level & Erosion Severity Level \\
\hline SW_1 & 15.40 & 20.10 & 3 & High \\
SW_2 & 13.34 & 17.28 & 4 & Moderate \\
SW_3 & 9.19 & 16.32 & 5 & Moderate \\
SW_4 & 1.66 & 9.07 & 8 & Slight \\
SW_5 & 5.28 & 44.34 & 1 & Very high \\
SW_6 & 8.64 & 7.36 & 9 & Slight \\
SW_7 & 14.40 & 9.61 & 7 & Slight \\
SW_8 & 14.28 & 13.84 & 6 & Moderate \\
SW_9 & 17.83 & 30.26 & 2 & Very high \\
Total & 100.02 & 168.021 & & \\
\hline Source: & & &
\end{tabular}

Source: - Adapted from Tesfaye et al., (2018)

Table 4: Annual potential soil erosion rates and severity classes in Jimma zone districts

\begin{tabular}{|c|c|c|c|c|c|c|c|c|}
\hline \multirow[t]{2}{*}{ Districts } & \multicolumn{2}{|c|}{$\begin{array}{l}\text { Low } \\
\text { (Affected } \\
\text { area \%) } \\
\end{array}$} & \multirow{2}{*}{$\begin{array}{l}\text { Moderate } \\
\text { area \%) } \\
2001\end{array}$} & (affected & \multicolumn{2}{|c|}{$\begin{array}{l}\text { High } \\
\text { (Affected } \\
\text { area \%) }\end{array}$} & \multicolumn{2}{|c|}{$\begin{array}{l}\text { Very high } \\
\text { area \% ) }\end{array}$} \\
\hline & 2001 & 2013 & & 2013 & 2001 & 2013 & 2001 & 2013 \\
\hline Sigmo & 98.4 & 96.3 & 1.2 & 2.9 & 0.3 & 0.6 & 0.1 & 0.2 \\
\hline Gera & 95.9 & 94.5 & 3.1 & 4.1 & 0.8 & 1.1 & 0.2 & 0.4 \\
\hline Setema & 93.2 & 86.4 & 5.2 & 10.1 & 1.0 & 2.3 & 0.5 & 1.1 \\
\hline Mena & 85.2 & 82.4 & 9.7 & 11.3 & 3.4 & 3.8 & 1.7 & 2.4 \\
\hline Goma & 76.7 & 75.3 & 11.6 & 11.5 & 6.1 & 6.7 & 5.6 & 6.5 \\
\hline Kersa & 64.5 & 58.3 & 17.9 & 17.6 & 10.0 & 11.6 & 7.6 & 12.4 \\
\hline $\begin{array}{l}\text { Seka } \\
\text { chekorsa }\end{array}$ & 75.1 & 74.3 & 10.9 & 10.8 & 5.4 & 5.6 & 8.5 & 9.3 \\
\hline Limu kosa & 68.8 & 60.1 & 11.9 & 13.1 & 7.0 & 9.3 & 12.2 & 17.4 \\
\hline Omo nada & 52.2 & 45.9 & 16.5 & 14.4 & 9.9 & 11.7 & 21.4 & 28.5 \\
\hline Dedo & 53.2 & 45.9 & 13.8 & 13.2 & 9.4 & 11.0 & 23.6 & 29.9 \\
\hline Tiro afeta & 46.3 & 41.6 & 13.3 & 9.9 & 14.4 & 13.1 & 26.0 & 35.4 \\
\hline Limu seka & 48.7 & 43.7 & 12.6 & 10.9 & 10.5 & 11.5 & 28.2 & 33.9 \\
\hline Sekoru & 39.9 & 38.3 & 13.8 & 11.6 & 12.4 & 13.2 & 33.8 & 37.0 \\
\hline
\end{tabular}

Source: - Adapted from Lencha and Moges (2015) 


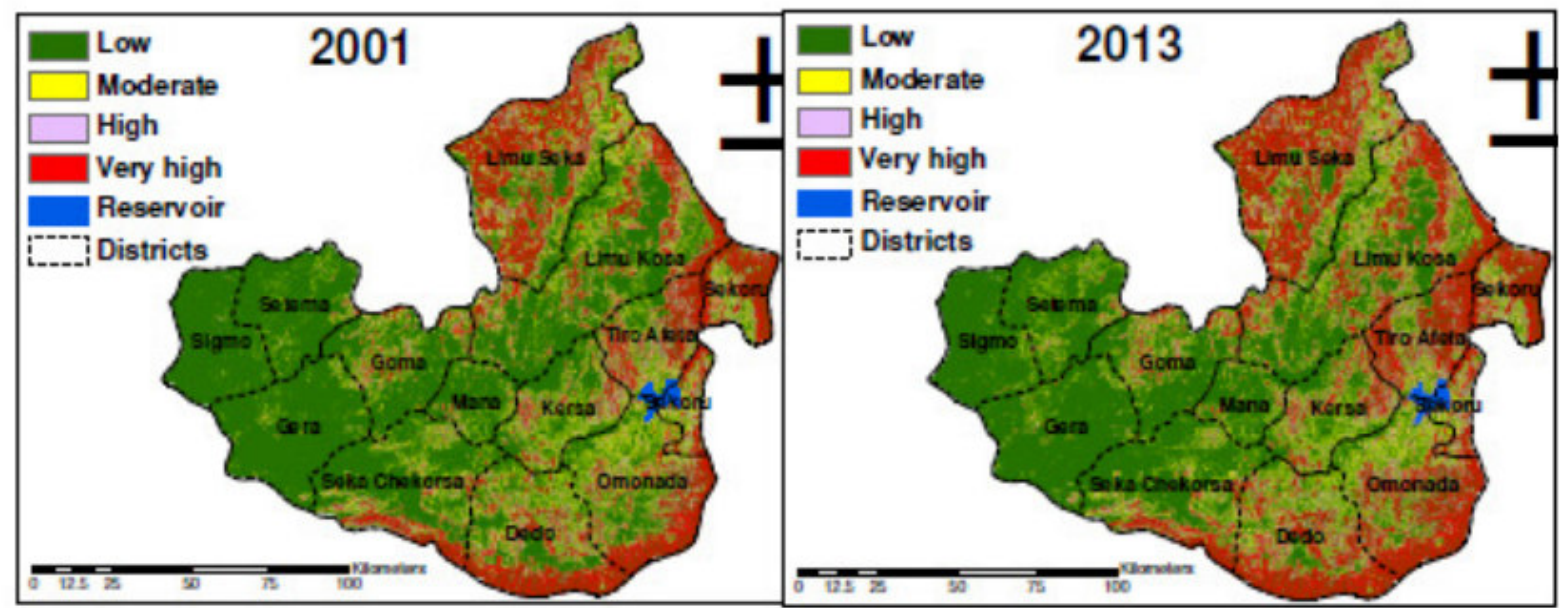

Figure 4: Erosion Susceptibility Levels for the year 2001 and 2013 (Lencha and Moges, 2015)

\subsection{GIS and RS for identifying the cause of soil erosion}

Land degradation activated by two major causes such as the natural and the human social system (Deresa and Legesse, 2015; Legesse et al., 2004; Broothaerts et al., 2012). The interconnection between human beings with the natural ecosystem is reflected as complex causes (Hailu, 2017; Berry, 2003; Hurni et. al, 2010; Deresa and Legesse, 2015; Worku et al., 2014).

Soil erosion is the main feature of land degradation, it can be geological, which created through a natural process within a long period while accelerated type occurred by human interference (Mitiku et al., 2006).

Often it is too difficult to understanding and identifying the cause of soil erosion. However, GIS and RS play a great role in identifying the cause of soil erosion or land degradation by the following two methods. One method, GIS and RS techniques integrates with USLE or RUSLE soil erosion model's parameters. The second method, simultaneously assessing by using both GIS and RS integrate with USLE or RUSLE as well as field survey and community survey (Bekele et al, 2018a, Worku et al., 2014; Temesgen et al., 2017).

All necessary information about the cause of land-use variation can be extracted from remotely sensed data, which helps for assessing the level of land degradation, the status of land use and land cover change, evaluation and monitoring management level of a natural resource. Therefore, to evaluated land-use change, remotely sensed imagery has a tiger share in providing information about the temporal trends and spatial distribution, and changes over time measurement for land-use changes. A more systematic approach like GIS-based erosion modeling (USLE based on GIS) which is a flexible, timesaving and cost-effective tool can be used instead for larger-scale studies.

Improperly land use land cover change (LULCC) acts as a catalyst for soil degradation. It may too difficult to assess its change and its impacts from a large scale by manual method. Therefore, GIS and RS can solve this issue.

There is a few researchers have assessed LULCC by using GIS and RS in different parts of the country. For example, Worku et al (2014) from Ameleke watershed, South Ethiopia, Bekele et al (2018a) and Bekele et al (2018b) from central rift valley lake of Ethiopia, Dinka and Chaka (2019) from Adei watershed, Central Highlands of Ethiopia and Degife (2018) from Abobo District of Gambella region and Gashaw et al (2014) from in Dera district, Ethiopia.

LULCC already categorized as a catalyst for land degradation in form soil erosion in central rift valley lakes of Ethiopia (Bekele et al., 2018a). Land-use changes can alter or affect the hydrological flow direction, which highly enforced to increase surface runoff (especially during the study period from 1986 to 2009) due to the sever expansion of agricultural land to forest, grassland and shrubland (Demeke and Andualem, 2018). Besides, a study conducted by Gashaw et al (2014) by using GIS and Remote Sensing in Dera District, Ethiopia, shows that due to LULCC, land degradation was watchfully increasing within the last 26 years (1985-2011); people become intruding and cultivating of marginal and sloppy land. Land use (e.g. Forest, shrub, and grass) were altered into cultivate and degraded land unkindly (Table 5). In other words, the amount of land exposed to soil erosion is increased by $995.49 \mathrm{ha}(25.79 \%)$ and $395.37 \mathrm{ha}(398 \%)$ from 1985 to 2011.

Furthermore, Degife (2018) reported that LULCC increase by various complexity force, but population growth imposes high pressure for the changing of forest and savanna land into farmland, which in turn increase environmental degradation particularly soil erosion (barren land). When land degradation level is at dangerous stages (bare land), there is high splash erosion, high runoff, less infiltration and high evaporation (Figure 5a) and inverse where the land covered by various vegetation (Mitiku et al., 2006) (Figure 5b). Therefore, other studies 
also confirmed that soil erosion increase (soil loss) under such circumstance. The main point to consider in LULCC is that there is a hide external driving force, which may enforce to emerge LULCC. Obliviously, it is continuously dynamic and interlocked with land degradation.

Further, GIS and RS couples with USLE or RUSL can isolate the causes of soil erosion. For example, Lencha and Moges (2015) identified the factors in Jimma Zone (Figure 6). In other views, improper LULCC is directly or indirectly connected with the most commonly known of USLE or RUSLE parameters. They also called spatial variability and they are a key determinate of soil erosion risks (Tesfahunegn et al., 2014). Many scholars confirmed that land degradation in form soil erosion influenced by biophysical factors most of them are included in USLE or RUSLE factors.

For instance, among RUSLE factors, slope length and slope gradient (LS) is the most significant factors followed by soil erodibilty factor $(\mathrm{K})$ in Koga watershed, which identified by GIS technique (Gelagay and Minale, 2016). This is due to the fact reason that there is a narrow steepest slope at upper parts of watershed and types of soil available are highly susceptible to soil erosion (e.g. Haplic Nitosols, Regosoils, and Haplic Luvisols) each may have K-value ranges from 0.2- 0.25. Similarly, Lencha and Moges (2015) also reported that soil erosion severity is very high in four districts of the Jimma zone. Such as Sekoru, Dedo, Tiro afeta, Omo Nadda and Limu seka, where the value of R-factor (show high rainfall intensity), C-factor (show low forest coverage or high agrarian area), LS-factor (undulating topography) and P-factor (less conservation practice) is high and soil is highly susceptible to soil erosion than other districts (e.g. Goma, Setama, Gera and Sigmo). As a result, five districts already recognized under the very severity of soil erosion and soil erosion is increasing whereas a decrease in the above-mentioned three districts from 2001 to 2013 (Table 4) (Figure 6).

Gashaw et al. (2014) also ratified the impact of land cover change in Dera, by analyzing vegetation (forest) trends by calculating the Normalized Difference Vegetation Index (NDVI) by using the TM imagery of 1985 and ETM+ of 2011. Accordingly, they found the maximum value of NDVI decreased from 0.83 in 1985 to 0.58 in 2011, which shows the declination of vegetation coverage which inversely triggering soil degradation (Table 5). At normal circumstances the NDVI is situated between -1 to 1 , this means when NDVI values -1 there is not vegetation coverage while when NDVI value 1 there is vegetation coverage. The general formula of USLE/RUSLE, which use for estimating soil loss and degree of each factor integrated and finally developing soil loss map with GIS and RS (Wischmeier and Smith, 1978) (Equation 1).

$\mathrm{A}=\mathrm{R} \times \mathrm{K} \times \mathrm{LS} \times \mathrm{C} \times \mathrm{P}$ equation 1

Where: $\mathrm{A}$ is estimated average soil loss in tons ha per year, $\mathrm{R}$ is rainfall-runoff erosivity factor, $\mathrm{K}$ is soil erodibility factor, $\mathrm{L}$ is slope length factor, $\mathrm{S}$ is slope steepness factor, $\mathrm{C}$ is a cover-management factor and $\mathrm{P}$ is support practice factor.

Remotely sensed data can contribute to the valuation of almost all these factors. The soil erodibility factor $\mathrm{K}$ is the measure of soil resistance to erosion; it strongly depends on the soil particle size, soil roughness, and organic matter content. Various soil properties may be effectively mapped using satellite images visual interpretation or image classification. Slope length factor L and slope steepness factor S represent the effect of slope length and slope steepness on erosion respectively. The cover-management factor reflects the effect of cropping and tillage on erosion rates. It consists of a few sub-factors: surface cover, canopy, soil roughness, moisture, and land use can obtain from satellite optical and radar images. The last factor from the USLE/RUSLE model, which can be supported with remotely sensed data, is the P factor, reflecting the impact of support practices on erosion rates. It takes into account the tillage method (for instance strip cropping, straight row farming, up-and-down slope tillage) see from the flow chart (Figure 1). Similarly, Wubie (2015) concluded the reason why soil loss rate varied within the same watershed that due to slope variation, poor land management, land over-cultivation, overgrazing and land not covered by vegetation, especially during raindrops period. Furthermore, Tesfaye et al (2018) revealed the severity of soil loss is increase at the outlet and at inlet upper parts of the watershed where land slope and crop cultivation intensive high. This due to the increment of flood at a lower slope and there is a high concentration of water, a reason for a high run-off.

In addition to biophysical factors, soil degradation prompted by many complex factors such as human being activity and economic development. Socio-economic and demographic factors have aided the acceleration of soil erosion, particularly in developing countries. Increasing population, deforestation, land cultivation, uncontrolled grazing and growing demands for firewood are often the causes of soil erosion (Reusing et al., 2000). For example, the study conducted in Megech River catchment, Northwestern Ethiopia by Veeranarayana et al (2019) on soil erosion using RUSLE integrate with GIS and RS distinguished the major cause of soil erosion in the watershed. Accordingly, they reported population pressures as the major cause because almost all the rest they list was happened due to people's activities such as deforestation, traditional farming system, lack of soil management, insecurity in land tenure, the encroachment of people into marginal land, changing steep slope to cultivation and uncontrolled grazing. Coincides to this concept Demeke and Andualem (2018) confirmed that population size increment is the root cause for land-use changes in Muga watershed (study area) which found in Upper Blue Nile Basin. 
Therefore, GIS and RS contribute incredible benefits in distinguishing the cause of soil erosion. Generally, two major causes of soil erosion are already declared by using various methods commonly all over the world such as natural and anthropogenic. However, in this paper, the availability of those causes is reviewed from various previous a study conducted only newly emerged technology; GIS and RS, GIS and RS with USLE. From this review, natural and anthropogenic causes are the dominant cause a previously announced. USLE parameters are playing a major role in determining to trigger or defusing of soil degradation. Either directly or indirectly, there is the interconnection of a social system and economic development with the USLE factors. Even a few perhaps happened in a natural process, people pressure is accounted as the dominant driving force particularly for LULCC. LULCC is the principal cause of soil degradation (Halefom et al., 2018).

Table 5: LU/LC changes between 1985 and 201 in Dera districts, Ethiopia

\begin{tabular}{|c|c|c|c|c|c|c|c|}
\hline \multirow[t]{2}{*}{ LULC class } & \multicolumn{2}{|l|}{1985} & \multicolumn{2}{|l|}{2011} & \multirow{2}{*}{$\begin{array}{l}\text { Change in ha } \\
(1985-2011)\end{array}$} & \multirow{2}{*}{$\begin{array}{l}\text { Rate of change } \\
\text { in ha/year }(1985 \\
-2011)\end{array}$} & \multirow{2}{*}{$\begin{array}{l}\text { Percentage } \\
\text { change } \\
(\mathbf{1 9 8 5 - 2 0 1 1 )}\end{array}$} \\
\hline & Area & $\%$ & Area & $\%$ & & & \\
\hline Waterbody & 38.79 & 0.53 & 35.64 & 0.48 & -3.15 & -0.12 & -8.12 \\
\hline Forest & 706.41 & 9.6 & 310.14 & 4.22 & -396.27 & -15.24 & -56.09 \\
\hline Shrub & 1408.32 & 19.14 & 464.4 & 6.31 & -943.92 & -36.3 & -67.07 \\
\hline Grass & 1243.98 & 16.91 & 1196.46 & 16.26 & -47.52 & -1.83 & -3.81 \\
\hline Cultivated & 3859.74 & 52.47 & 4855.23 & 66 & +995.49 & +38.29 & +25.79 \\
\hline Degraded & 99.36 & 1.35 & 494.73 & 6.72 & +395.37 & +15.2 & +398 \\
\hline Total area & 7356.6 & 100 & 7356.6 & 99.99 & & & \\
\hline
\end{tabular}

Source: Undated from Gashaw et al (2014)

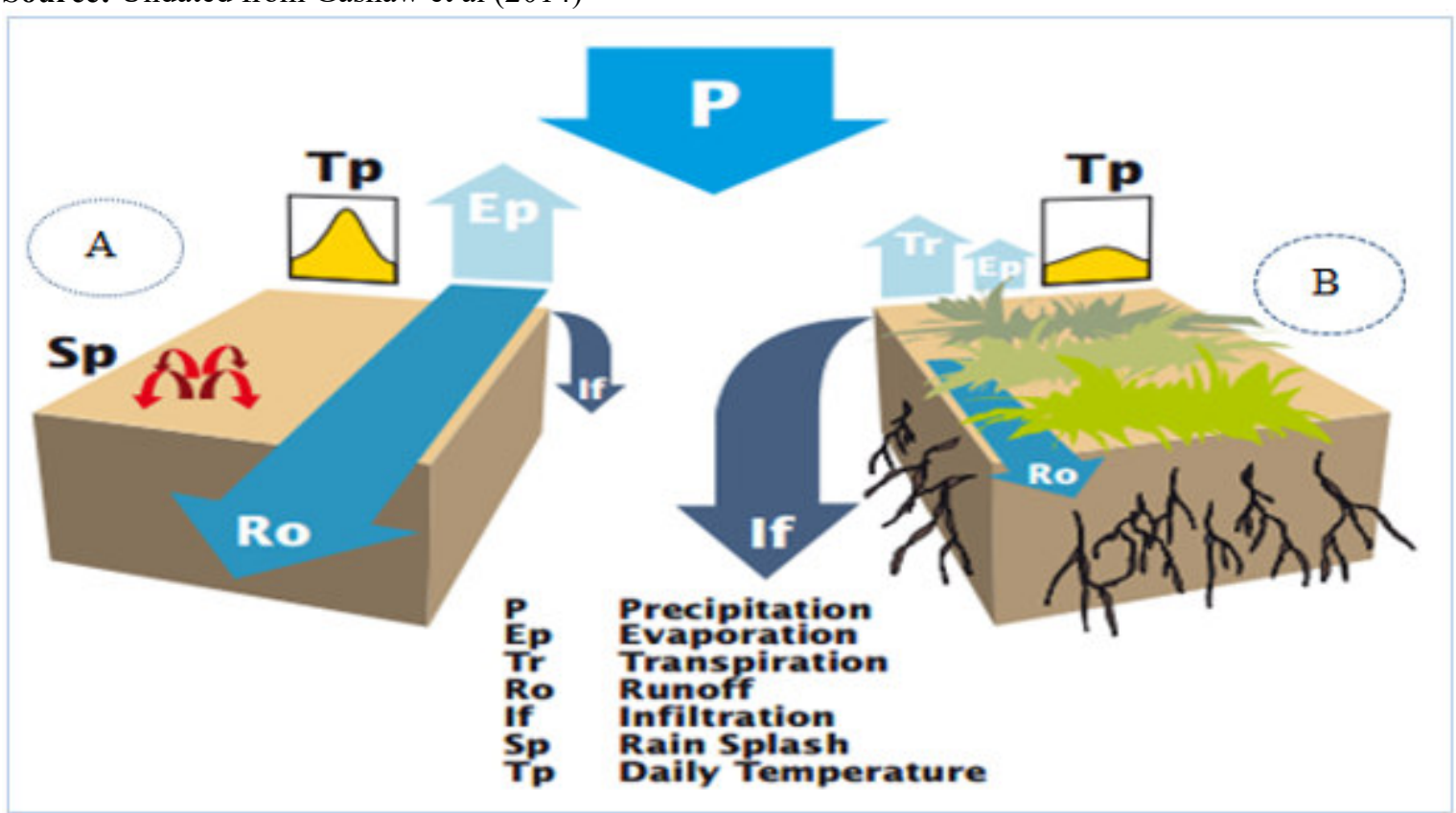

Figure 5: Influence of vegetation on soil erosion 


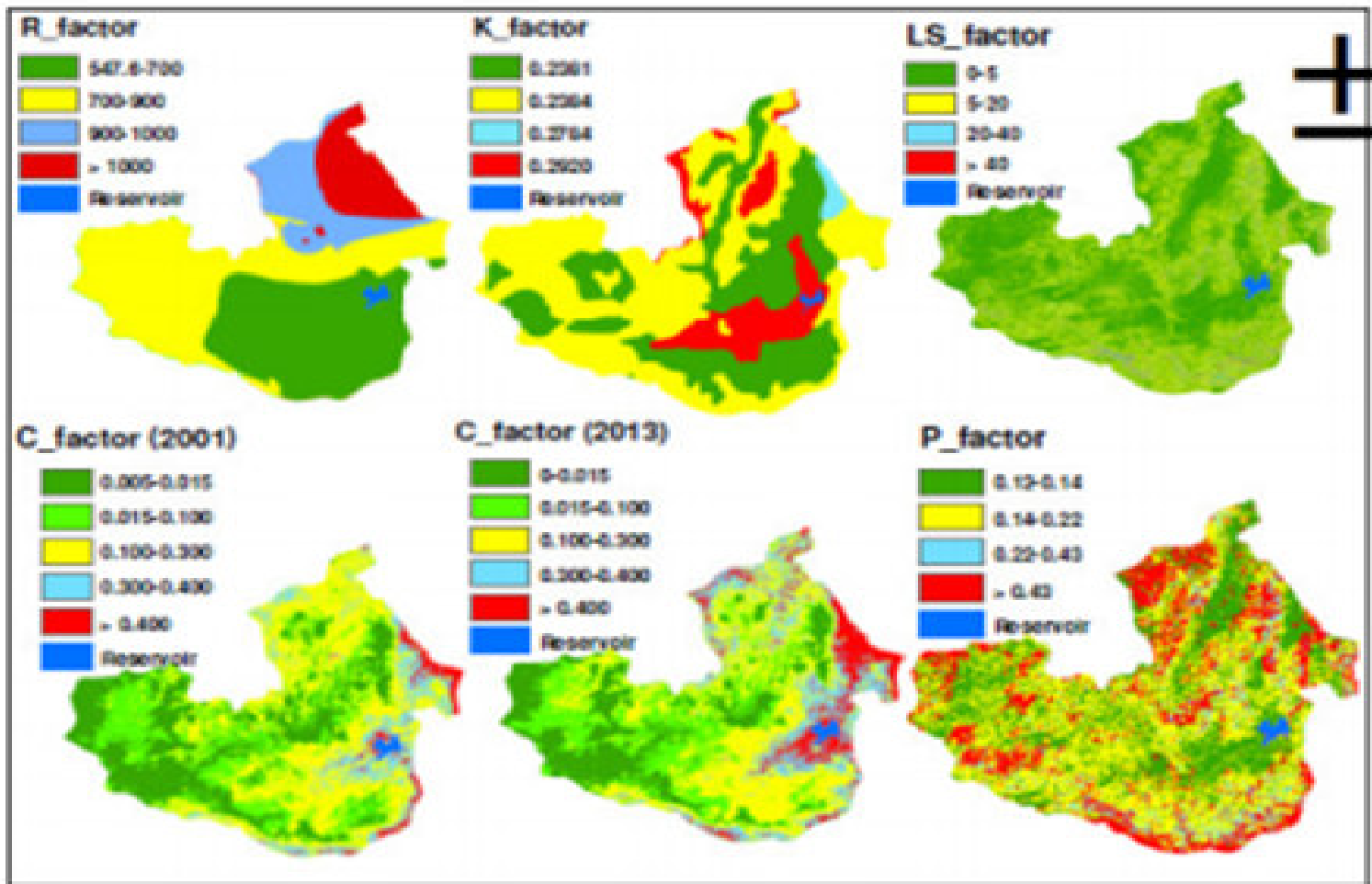

Source: Drawing: Karl Herweg, cited in Mitiku et al., (2016)

Figure 6: Factors of USLE in Jimma zone (Lencha and Moges, 2015)

\subsection{GIS and RS for assessing the consequences of soil erosion}

Obviously, the consequence of soil erosion is negative often. Soil degradation is manifested itself in terms of threatening economic growth, environment and social all over the world including Ethiopia. Nevertheless, its severity rate is varying from country to country and from place to place. Its impact is very severe in developing countries due to two main reasons; first, their life is directly connected with soil, so when top productive soil loss it directly affect their economic development and livelihoods of farmers. Second, they have less ability to adapt because of their economic level. In broadly terms, the impact of soil erosion categorized into on-site and off-site effects (Mitiku et al., 2006; Lencha and Moges, 2015; Gizaw and Degifie, 2018). Noticeably, soil erosion has three basic procedures such as detachment or displacement, transportation and deposition of the soil particle at the downstream area by wind, water, or gravitational forces (Mitiku et al., 2006; Boardman, 2013).

Soil erosion and its impacts are inseparable terms. The on-site effect refers to the place where the top productive soil removed from and off-site effects refer to the place where the eroded soil becomes deposit (Mitiku et al., 2006).

Precisely identifying the negative impacts of soil erosion needs more time and financial resources. Especially getting information from an inaccessible place like Northern parts of the country where complex terrains are dominant is jeopardizes. However, RS can solve it. Besides, GIS and RS join with USLE or RUSLE or alone can smooth this problem. This issue confirmed by numerous researchers' findings.

In Ethiopia, both off-site and on-site effect is the greatest chronic problems currently. As different studies depicted that many lakes, reservoirs (dams) and irrigation channels are rapidly declining due to soil sediment. Flash floods, water pollution and sedimentation of water reservoirs are common. For example, Gilgel Gibe I hydroelectric power is threatening by sediment (Lencha and Moges.2015; Gizaw and Degifie, 2018). Besides, Gilgel Gibe II also faced similar problems because the water used in Gilgel Gibe-I also reused in Gilge gibe-II (Demissie et al., 2013). As a result, the water storing capacity of reservoirs is diminishing in which in turn limits the amount of hydroelectric power to be generated. Not only this but also indirectly or directly it can undermine the economic growth (decline export power) of the country, deteriorate people's livelihood, shorten a lifespan in further it increases maintenance cost (Figure 7).

In addition to off-site effects, there is an on-site effect (Figure 7). Therefore, one impact of soil degradation is the deterioration of soil chemical properties (salinization, acidification, and salinization). This could examine by GIS and RS techniques. For example, Asfaw et al., (2018) conducted a study on soil salinity in Wonji sugar cane irrigation farm, Ethiopia using RS integrate with salinity model, acknowledged that around $80 \%$ of the land area is highly affected by saline concentration. As a result, soil properties affected, in turn, reduce crop yield. 
Soil erosion highly affects both chemical and physical quantity of soil, in which soil nutrient deficiency reflected (Rabia, 2012). Socio-economic and environment, soil productivity decline, land degradation, shortage of wood, shortage of grazing land, climate change, soil erosion, loss of biodiversity and lake water withdrawal are some of the basic challenges happened due to land degradation through LULCC in central rift valley lakes of Ethiopia (Bekele et al., 2018a). As previously discussed under soil loss estimations, the amount of soil loss was almost all above the maximum soil loss tolerant (18 t ha year) standard given for Ethiopia (Hurni, 1985a). Particularly, in the highland of Ethiopia, estimate soil loss rate from arable go up to $130 \mathrm{tha}-1 \mathrm{y}-1$ with a mean of $35 \mathrm{tha}-1$ $\mathrm{y}-1$ from total land-use types (FAO, 1986).

The main core of the on-site effect is diminishing the productive capacity of the soil, by removing fertile soil, which in turn reduces crop yields. About 1.5 billion tons of soil loss registered annually in Ethiopia (FAO, 1986). In highland parts, the productive potential of the land is reducing by $2.2 \%$ per year (Tesfahunegn et al., 2014; FAO, 1986). Soil erosion has both effects; reduce crop yield and destroy irrigation channels (Gelagay and Minale, 2017). This is a very great challenge for Ethiopian people's livelihood because agriculture is fundamental for more than $85 \%$ of people of Ethiopia (FDREPCC, 2008). It contributes $45-50 \%$ GDP of the country's economy, over $90 \%$ of employees participated in this sector and over $90 \%$ of foreign exchange earnings (ECACC, 2002). Besides, the basic sector for all other sectors.

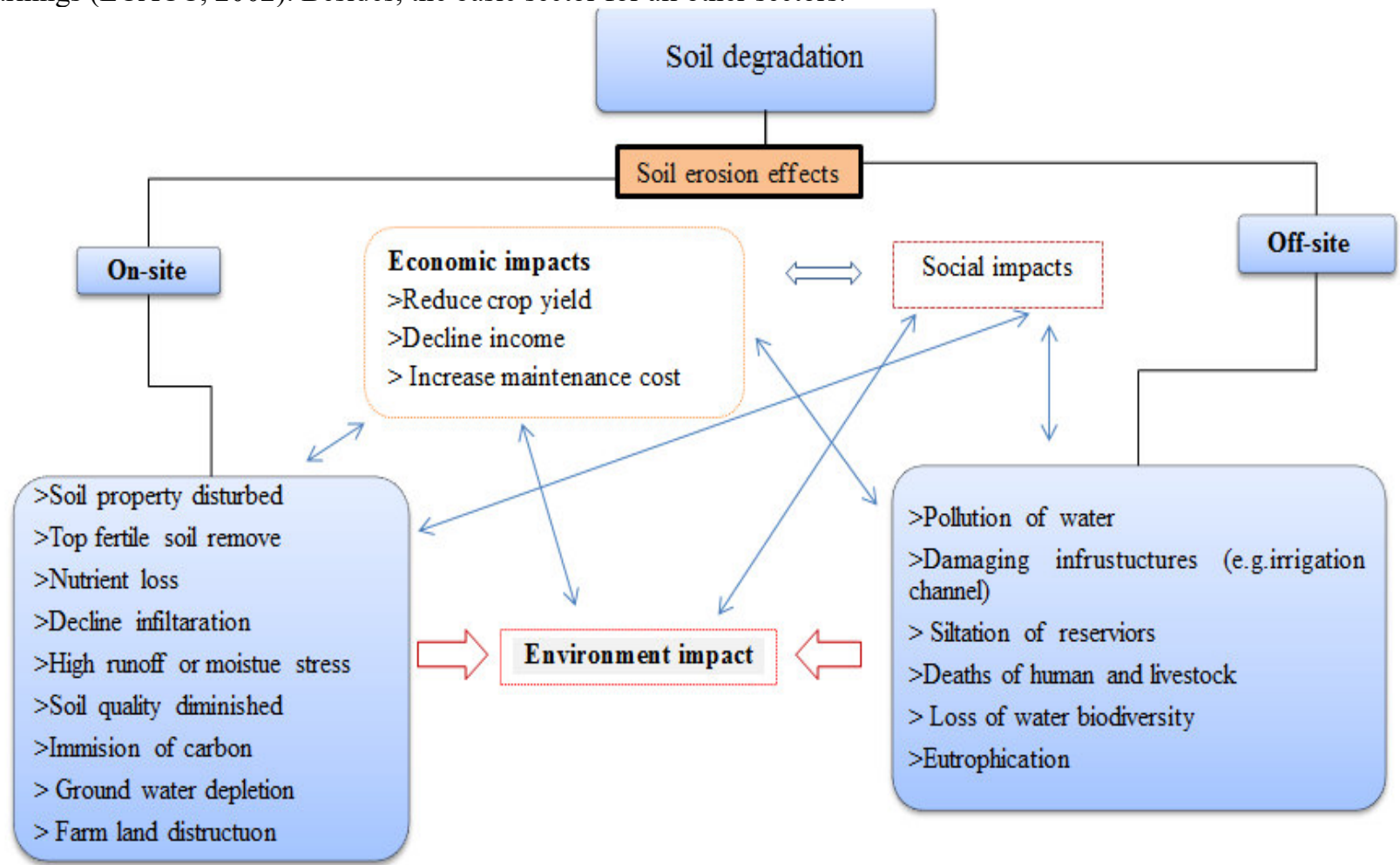

Figure 7: Effects of soil degradation

Source: Combined from (Lal, 2001; Lencha and Moges, 2015; Temesgen et al., 2017; Asfaw et al., 2018; Tesfaye et al., 2018; Gizaw and Degifie, 2018).

\section{Conclusion and recommendations}

Soil degradation is a critical agenda in developing countries including Ethiopia. It is triggering by water soil erosion. Because of soil erosion, the potential capacity of the soil highly deteriorated. Consequently, agricultural crop yield is declining inversely food insecurity and poverty increasing, and then finally it diminishing the livelihood of people. Generally, it threatens economic growth, environmental resource, and social assets.

The effect of soil erosion is unevenly distributed. It is too difficult to identify the status of soil degradation, estimate the amount of soil loss, cause of soil erosion and its consequence by manual methods. Because in manual method; it impossible to caver large are within a short time besides problems of inefficiency and inaccuracy.

However, GIS and RS techniques contribute incredible benefits in solving the aforementioned problems. Particularly RS helps in collecting data from an inaccessible difficult place. In watershed delineation, soil loss estimation and prioritization GIS and RS couple with USLE or RSLE soil erosion model. Even though a few studies conducted on soil degradation by this technique, many people overlook the contribution of GIS and RS. Therefore, the government and all concerned bodies should change their attention to the utilization of GIS and 
RS for natural resource management. Besides, the government should encourage the expert and other concerned bodies to connect all-natural resource management with GIS and RS.

\section{Reference}

Amsalu, T. and Mengaw, A., 2014. GIS based soil loss estimation using rusle model: the case of jabi tehinan woreda, ANRS, Ethiopia. Natural Resources, 5(11), p.616.

Asfaw, E., Suryabhagavan, K.V. and Argaw, M., 2018. Soil salinity modeling and mapping using remote sensing and GIS: The case of Wonji sugar cane irrigation farm, Ethiopia. Journal of the Saudi Society of Agricultural Sciences, 17(3), pp.250-258.

Ayalew, G. and Selassie, Y.G., 2015. Soil loss estimation for soil conservation planning using geographic information system in Guang watershed, Blue Nile basin. J. Environ. Earth Sci, 5, pp.126-134.

Ayalew, G., 2015. A Geographic Information System Based Soil Loss and Sediment Estimation in Zingin Watershed for Conservation Planning, Highlands of Ethiopia. International Journal of Science, Technology and Society, 3(1), p.28.

Bekele, B., Wu, W., Legesse, A., Temesgen, H. and Yirsaw, E., 2018b. Socio-environmental impacts of land use/cover change in Ethiopian central rift valley lakes region, East Africa. Applied Ecology and Environmental Research, 16(5), pp.6607-6632.

Bekele, B., Wu, W., Legesse, A., Temesgen, H., Yirsaw, E. (2018a): Random and systematic land use/land cover transitions in semi-arid landscapes of Ethiopian Central Rift Valley Lakes Region (East Africa). Applied Ecology and Environmental Research 16: 3993-4014.

Berry, L., 2003. Land degradation in Ethiopia: its impact and extent in Berry L, Olson J. and Campbell D (ed): Assessing the extent, cost and impact of land degradation at the national level: findings and lessons learned from seven pilot case studies. Commissioned by global mechanism with support from the World Bank, pp.112.

Bewket, W. and Teferi, E., 2009. Assessment of soil erosion hazard and prioritization for treatment at the watershed level: case study in the Chemoga watershed, Blue Nile basin, Ethiopia. Land Degradation and Development, 20(6), pp.609-622.

Boardman, J., 2013. Soil erosion in Britain: updating the record. Agriculture, 3(3), pp.418-442.

Broothaerts, N., Kissi, E., Poesen, J., Van Rompaey, A., Getahun, K., Van Ranst, E. and Diels, J., 2012. Spatial patterns, causes and consequences of landslides in the Gilgel Gibe catchment, SW Ethiopia. Catena, 97, pp.127-136.

Chernet., D,. 2018. Micro Watershed Development Using GIS \& Remote Sensing in the Case of Chille and Ocholo Watersheds, Duguna Fango Woreda, Wolaita Zone, Southern Nations Nationalities and Peoples Region, Ethiopia. Journal of Environment and Earth Science; 8(2).

Degife, .A.W., 2018. Assessment of Land Use and Land Cover Change Using GIS and Remote Sensing Techniques: A Case Study of Abobo District, Gambella Region, Ethiopia. Paper prepared for presentation at the world bank.

Demeke, G.G. and Andualem, T.G., 2018. Application of Remote Sensing for Evaluation of Land Use Change Responses on Hydrology of Muga Watershed, Abbay River Basin, Ethiopia. J Earth Sci Clim Change, 9(493), p.2.

Demissie, T.A., Saathoff, F., Seleshi, Y. and Gebissa, A., 2013. Evaluating the Effectiveness of Best Management Practices in Gilgel Gibe Basin Watershed-Ethiopia. Journal of Civil Engineering and Architecture, 7(10), p.1240.

Deresa, F. and Legesse, T., 2015. Cause of land degradation and its impacts on livelihoods of the population in Toke Kutaye Woreda, Ethiopia. International Journal of Scientific and Research Publications, 5(5), p.9.

Dinka, M.O. and Chaka, D.D., 2019. Analysis of land use/land cover change in Adei watershed, Central Highlands of Ethiopia. Journal of Water and Land Development, 41(1), pp.146-153.

Emiru, T.S. and Taye, A.A., 2012. Land use/cover dynamics in lowland Ethiopia since 1957: the case of Mandura district, Benshangul-Gumuz Regional State. Journal of Biodiversity and Environmental Sciences, 8, pp.36-49.

Estifanos, A., 2014. Assessment of micro-watershed vulnerability for soil erosion in Ribb watershed using GIS and remote sensing (Doctoral dissertation, Mekelle University).

Ethiopian Central Agricultural Census Commission (ECACC) (2002). Report on Preliminary Results of Area, Production and Yield of Temporary Crops (Meher Season Private Peasant Holding), Part II, on Ethiopian Agricultural Sample Enumeration, Addis Ababa, Ethiopia.

Ethiopian highland reclamation study: 1986. ," Final Report, FAO, Rome, Italy,.

Federal Democratic Republic of Ethiopia Population Census Commission (FDREPCC) .2008. Summary of statistical report of the 2007 population and housing census. Addis Ababa, Ethiopia.

Fenta, A.A., Yasuda, H., Shimizu, K., Haregeweyn, N. and Woldearegay, K., 2017. Quantitative analysis and 
implications of drainage morphometry of the Agula watershed in the semi-arid northern Ethiopia. Applied Water Science, 7(7), pp.3825-3840.

Fikru, A, .1990. The role of land use planning in the improvement of natural resources management: In National Conservation Strategy Conference. Vol. 3.

Food and Agriculture Organization (FAO) .1984. Ethiopian Highland reclamation Study (EHRS). Final Report, Vol: 1 and 2, Rom

Food and Agriculture Organization (FAO). 1986. Ethiopian Highland Reclamation Study; Final Report; Rome, Italy, pp. 37-46.

Gashaw, T., Bantider, A. and Mahari, A., 2014. Evaluations of land use/land cover changes and land degradation in Dera District, Ethiopia: GIS and remote sensing based analysis. International Journal of Scientific Research in Environmental Sciences, 2(6), p.199.

Gebre, T., Kibru, T., Tesfaye, S. and Taye, G., 2015. Analysis of watershed attributes for water resources management using GIS: The case of Chelekot micro-watershed, Tigray, Ethiopia. Journal of Geographic Information System, 7(02), p.177.

Gelagay, H.S. and Minale, A.S., 2016. Soil loss estimation using GIS and Remote sensing techniques: A case of Koga watershed, Northwestern Ethiopia. International Soil and Water Conservation Research, 4(2), pp.126-136.

Gizaw T, Degifie T. 2018. Soil Erosion Modeling Using GIS Based RUSEL Model in Gilgel Gibe-1 Catchment, South West Ethiopia. Int J Environ Sci Nat Res; 15(5)

Hailu. Z., 2017. Impact of Physical Soil and Water Conservation Structure on Selected Soil Physicochemical Properties in Gondar Zuriya Woreda, Resources and Environment, 7(2): 40-48

Halefom, A., Teshome, A., Sisay, E., Khare, D., Dananto, M., Singh, L. and Tadesse, D., 2018. Applications of Remote Sensing and GIS in Land Use/Land Cover Change Detection: A Case Study of Woreta Zuria Watershed, Ethiopia. Applied Research Journal of Geographic Information System, 1(1), pp.1-9.

Hurni, H., Abate, S., Bantider, A., Debele, B., Ludi, E., Portner, B., Yitaferu, B. and Zeleke, G., 2010. Land degradation and sustainable land management in the highlands of Ethiopia.

Hurni.H., 1985a. "Erosion-productivity-conservation systems in Ethiopia," in Soil Conservation and Productivity, Proceeding of the 4th International Conference on Soil Conservation, I. P. Sentis, Ed., pp. 654-674, Maracay, Venezuela.

Kaltenrieder, J. 2007. Adaptation and Validation of the Universal Soil Loss Equation (USLE) for the EthiopianEritrean Highlands. MSc Thesis, University of Berne, Centre for Development and Environment Geographies Institut.

Lakew, D., Carucci, V., Asrat, W. and Yitayew, A., Eds. 2005. Community Based Participatory Watershed Development. Ministry of Agriculture and Rural Development, Addis Ababa, Ethiopia.

Lal, R.A.T.T.A.N., 2001. Soil degradation by erosion. Land degradation \& development, 12(6), pp.519-539.

Lencha, B.K. and Moges, A., 2015. Identification of soil erosion hotspots in Jimma zone (Ethiopia) using GIS based approach. Ethiopian journal of environmental studies and management, 8(2), pp.926-938.

Lulseged, T. and Vlek, P.L.G., 2005, September. GIS-based landscape characterization to assess soil erosion and its delivery potential in the highlands of northern Ethiopia. In Proceedings of the 1st International Conference on Remote Sensing and Geoinformation Processing in the Assessment and Monitoring of Land Degradation and Desertification, (ICRS '05) (pp. 7-9).

McNeill, R., 2000. Something New Under the Sun. W.W. Norton and Company, Inc.New York, NY.

Megersa, T., Nedaw, D. and Argaw, M., 2019. Combined effect of land use/cover types and slope gradient in sediment and nutrient losses in Chancho and Sorga sub watersheds, East Wollega Zone, Oromia, Ethiopia. Environmental Systems Research, 8(1), p.24.

Mekonnen, M., Keesstra, S.D., Baartman, J.E., Ritsema, C.J. and Melesse, A.M., 2015. Evaluating sediment storage dams: structural off-site sediment trapping measures in northwest Ethiopia. Cuadernos de investigación geográfica, 41(1), pp.7-22.

Mekuriaw, A., Heinimann, A., Zeleke, G., Hurni, H. and Hurni, K., 2017. An automated method for mapping physical soil and water conservation structures on cultivated land using GIS and remote sensing techniques. Journal of geographical sciences, 27(1), pp.79-94.

Mitiku. H. Karl. H,. Brigitta. S,. 2006. Land Resources Management and Environmental Protection Department Mekelle University, Ethiopia, and Centre for Development and Environment (CDE), Swiss National Centre of Competence in Research (NCCR) North-South University of Bern, Switzerland

Nyssen, J., Poesen, J., Moeyersons, J., Deckers, J., Haile, M. and Lang, A., 2004. Human impact on the environment in the Ethiopian and Eritrean highlands - a state of the art. Earth-science reviews, 64(3-4), pp.273-320.

Rabia, A.H. 2012, "GIS Spatial Modeling for Land Degradation Assessment in Tigray, Ethiopia", $8^{\text {th }}$ International Soil Science Congress on "Land Degradation and Challenges in Sustainable Soil 
Management", Çeşme - Izmir, Turkey, Ege University, May 15-17, volume 3, pp. 161:167.

Reusing, M., Schneider, T., Ammer, U., 2000. Modeling soil loss rates in the Ethiopian Highlands by integration of high resolution MOMS- 02/D2-stereo-data in a GIS. Journal of Remote Sensing 21 (9), pp.1885-1896.

Sertsu, S., 2000, September. Degraded soils of Ethiopia and their management. In Proc. 2nd Network Meeting FAO/ISCW expert consultation on management of degraded soils in Southern and East Africa, Subregional Office for Southern and East Africa. pp. 18-22.

Tamene, L.; Vlek, P.L.G.2005. GIS-based landscape characterization to assess soil erosion and its delivery potential in the highlands of northern Ethiopia. In Proceedings of the 1st International Conference on Remote Sensing and Geo-information Processing in the Assessment and Monitoring of Land Degradation and Desertification, Trier, Germany, 7-9 September; pp. 332-339

Tamirie, H., 1997. Desertification in Ethiopian Highlands, Norwegian Church AID Addis Ababa Ethiopia. RALA Report No. 200.

Temesgen, G,. Taffa, T,. and Mekuria,. 2017. Erosion risk assessment for prioritization of conservation measures in Geleda watershed, Blue Nile basin, Ethiopia. Environmental system research; 6:1

Tesfahunegn, G.B., Tamene, L. and Vlek, P.L., 2014. Soil erosion prediction using Morgan-Morgan-Finney model in a GIS environment in Northern Ethiopia catchment. Applied and Environmental Soil Science, 2014.

Tesfaye, G., Debebe, Y. and Fikirie, K., 2018. Soil Erosion Risk Assessment Using GIS Based USLE Model for Soil and Water Conservation Planning in Somodo Watershed, South West Ethiopia. International Journal of Environmental and Agriculture Research, 4 (5): 35, 43.

Tiruneh, G. and Ayalew, M., 2015. Soil loss estimation using geographic information system in enfraz watershed for soil conservation planning in highlands of Ethiopia. International Journal of Agricultural Research, Innovation and Technology, 5(2), pp.21-30.

Tsegaye, D., Moe, S.R., Vedeld, P. and Aynekulu, E., 2010. Land-use/cover dynamics in Northern Afar rangelands, Ethiopia. Agriculture, ecosystems and environment, 139(1-2), pp.174-180.

Wischmeier, W.H. and Smith, D.D., 1978. Predicting rainfall erosion losses: a guide to conservation planning (No. 537). Department of Agriculture, Science and Education Administration.

Woldemariam, G., Iguala, A., Tekalign, S. and Reddy, R., 2018. Spatial modeling of soil erosion risk and its implication for conservation planning: the case of the Gobele watershed, east Hararghe zone, Ethiopia. Land, 7(1), p.25.

Worku .G., Temsgen. H., Bantedir., A., 2014. Land use and land cover change in Ameleke Watershed, South Ethiopia. Journal of Natural Sciences Research; Vol.4, No.14

Wubie, A.M., 2015. GIS Based Land Degradation Assessment for Sustainable Land Management: The Case of Bench Maji Zone, Ethiopia, Africa; Journal of Research and Innovations in Earth Science 2(2). 